\title{
Characteristics of nodule bacteria from Mimosa spp grown in soils of the Brazilian semiarid region
}

\author{
Ana Dolores Santiago de Freitas ${ }^{1 *}$, Wardsson Lustrino Borges ${ }^{2}$, Monaliza Mirella de Morais \\ Andrade ${ }^{1}$, Everardo Valadares de Sá Barretto Sampaio ${ }^{3}$,Carolina Etienne de Rosália e Silva \\ Santos ${ }^{1}$, Samuel Ribeiro Passos ${ }^{4}$, Gustavo Ribeiro Xavier ${ }^{4}$, Bruno Mello Mulato ${ }^{4}$ \\ and Maria do Carmo Catanho Pereira de Lyra ${ }^{5}$ \\ ${ }^{1}$ Universidade Federal Rural de Pernambuco (UFRPE), Recife-PE, Brazil. \\ ${ }^{2}$ Embrapa Amapá, Macapá-AP, Brazil. \\ ${ }^{3}$ Universidade Federal de Pernambuco (UFPE), Recife-PE, Brazil. \\ ${ }^{4}$ Embrapa Agrobiologia, Seropédica-RJ, Brazil. \\ ${ }^{5}$ Instituto Agronômico de Pernambuco (IPA), Recife-PE, Brazil.
}

Accepted 13 January, 2014

\begin{abstract}
The Brazilian Northeastern dry forest (Caatinga) is one of the diversification centers of Mimosa species. We determined the characteristics of native rhizobia isolates from nodules of Mimosa tenuiflora and Mimosa paraibana grown in pots with soils collected under Caatinga vegetation and compared the restriction ribosomal DNA profiles of the isolates with those of 16 reference strains. All plants formed abundant indeterminate nodules and all nodule isolates formed fast growing colonies. No colony altered the medium to an alkaline reaction and most of them produced low or medium amounts of extracellular polysaccharides. White and creamy colonies predominated among the isolates but orange and green colonies were present. Differences among the isolates from the Mimosa species tested are indicated by the greater phenotypic diversity of those obtained from $M$. tenuiflora. The analysis of the 16S rDNA gene suggests that the isolates from $M$. tenuiflora and $M$. paraibana are closely related and closer to $\beta$ rhizobia than to $\alpha$-rhizobia. However, the similarity with all the tested $\beta$-rhizobia reference strains was relatively low suggesting that the isolates may belong to different bacteria species.
\end{abstract}

Key words: Biological nitrogen fixation, diversity, rhizobia, wild tree legumes.

\section{INTRODUCTION}

Legume species belonging to the genus Mimosa have received considerable attention in recent years because of their potential to fix large proportions of their nitrogen from the atmosphere (Freitas et al., 2010) and because of their preferential association with $\beta$-rhizobia (Chen et al., 2005; Barrett and Parker, 2006; Bontemps et al., 2010; Elliott et al., 2009; Reis Jr et al., 2010; Liu et al., 2012). Mimosa is one of the richest Leguminosae genera, with over 500 species, mostly neotropical, occupying diverse habitats, including lowland tropical rainforest, savanna, tropical and subtropical dry forest and thorn scrub, mid-elevation subtropical forest, desert, grassland, and wetland (Simon et al., 2011).

One of the diversification centers of Mimosa is the Brazilian Northeastern dry forest (Simon et al., 2011), locally called Caatinga. The Caatinga represents the largest and most isolated of the South American dry forests. It covers more than $850,000 \mathrm{~km}^{2}$ (Albuquerque et 
al., 2012), from $02^{\circ} 50^{\prime} S$ at its northern limits, to $17^{\circ} 20^{\prime} S$ with a variety of different types of vegetation (Queiroz 2006). Caatinga occurs under a prevailing semi-arid climate, with a high evapotranspiration potential (1500 to $2000 \mathrm{~mm}$ year $^{-1}$ ) and a low precipitation $(300-1000 \mathrm{~mm}$ year $\left.^{-1}\right)$ that is usually concentrated within 3 to 5 months (Queiroz 2006). The region is rich in legume species, with more than 293 speies in 77 genera, many of them endemic ones (Queiroz et al., 2009). Few of these species were studied in relation to their potential to fix nitrogen and to their microsymbionts (Freitas et al., 2010; Teixeira et al., 2010).

Mimosa paraibana Barneby and Mimosa tenuiflora (Willd.) Poir. are leguminous tree species with great nitrogen fixation capacity mean contributions of biological fixation for plant nitrogen reaching up to $50 \%$ in Caatinga (Freitas et al., 2010). M. tenuiflora is a species of wide distribution, occupying dry areas of Brazil to Mexico, Honduras and El Savador (Queiroz et al., 2009). This species is the main pioneer species in areas of caatinga with few years of regeneration (Souza et al., 2012). Its preferred symbionts are apparently $\beta$-proteobacteria, belonging to the genus Burkholderia (Bontemps et al., 2010; Reis Jr et al., 2010). Moreover, M. paraiba is a species endemic to Northeast Brazil (Queiroz et al., 2009) and there is no studies on bacteria capable of forming symbiotic nodules on their roots.

Research on Mimosa rhizobia have been conducted in several regions of Brazil (Chen et al., 2005; Barrett and Parker, 2006; Elliott et al., 2009; Liu et al., 2012). Isolation of rhizobia populations from Caatinga soils has been relatively rare (Bontemps et al., 2010; Reis Jr et al., 2010; Teixeira et al., 2010), mainly considering the diversity of environmental conditions in the region, that can affect the structure of rhizobia populations (Mishra et al., 2012). Moreover, most of this research centered on genetic characteristics and only Teixeira et al. (2010) described cultural characteristics of the rhizobia. Therefore, the diversity of bacteria able to nodulate Mimosa species in the region is little known.

Considering this scarcity of information, we characterized Caatinga native rhizobia associated to two Mimosa species in relation to their cultural traits and compared the restriction profiles of their amplified ribosomal DNA (16S rDNA-ARDRA) with those of 16 reference strains.

\section{MATERIALS AND METHODS}

\section{Soil sampling and Mimosa spp. cultivation}

Composite soil samples from the 0 to $20 \mathrm{~cm}$ superficial layer were collected in areas of preserved Caatinga vegetation in three municipalities, with different climate conditions (Table 1): 1) Santa Terezinha, in the sertão zone of Paraíba state; 2) Remígio, in the agreste zone of this same state; and 3) Serra Talhada, in the sertão zone of Pernambuco state. The composition and structure of the vegetation in the three areas were described by Ferraz et al.
(2003), Souza (2010) and Pereira et al. (2003), respectively. Number of species and tree heights and stem diameters are higher in the agreste zone than in the sertão zone and in this last zone higher in Serra Talhada than in Santa Terezinha, probably reflecting higher water availability.

Soil subsamples were analyzed for some chemical and physical characteristics (Table 2), following the methodology described by Embrapa (1997). The samples were dried, passed through a $6 \mathrm{~mm}$ mesh sieve and portions of $1 \mathrm{~kg}$ were placed in pots maintained under greenhouse conditions. Seeds of two Mimosa species (Mimosa tenuiflora (Willd.) Poir. and Mimosa paraibana Barneby) were collected from a single mother tree in Remígio caatinga. The seeds were surface disinfected in etanol $(70 \% \mathrm{v} / \mathrm{v}-3 \mathrm{~min})$ and sodium hypochlorite $(1 \% \mathrm{v} / \mathrm{v}-3 \mathrm{~min})$, rinsed five times with sterile distilled water, rolled onto YMA plates to test for surface sterility and then were sown in the pots. Each legume species was sown in triplicate for each soil sample. The pots received $100 \mathrm{ml}$ of nutrient solution without nitrogen (Hoagland and Arnon, 1939) every week until harvest, 120 days after seed germination. At harvest the root nodules were separated, dehydrated in silica gel and stored.

\section{Isolation and phenotypic characterization of rhizobia}

Rhizobia were isolated from the nodules in yeast mannitol agar medium (YMA, pH 6.8) (Vincent, 1970) with $25 \mathrm{mg} \mathrm{kg}^{-1}(\mathrm{w} / \mathrm{v})$ of Congo red. The typical rhizobia colonies were purified and stored at $-20^{\circ} \mathrm{C}$, in microtubes with $1 \mathrm{ml}$ YM medium(YMA without agar) plus $15 \%$ sterilized glycerol. Isolates colonies in YMA with $25 \mathrm{mg} \mathrm{kg}^{-1}$ $(\mathrm{w} / \mathrm{v})$ bromethymol blue as $\mathrm{pH}$ indicator (Fred and Waksman, 1958) were observed for the following characteristics: growth period, $\mathrm{pH}$ alteration of growth medium, colony morphology (shape, size, border, transparency, surface) and amount of extracellular polysaccharides (EPS) (Xavier et al., 1998). These characteristics were converted to binary data employed in a cluster analysis using the UPGMA (Unweighted Pair Group Method Using Arithmetic Averages) algorithmand the Jaccard similarity index.

The results of the cluster analysis were used to calculate richness (Taxa S and Margalef), diversity (Shannon $\mathrm{H}$ ), dominance (Simpson 1-D) and uniformity (Equitability $\mathrm{J}$ ) indices for the soils and species, where each morphological group, at $60 \%$ of the similarity (Jesus et al., 2005), was considered as one operational taxonomic unit. The Past (palaeontological statistics) program was used to perform cluster analysis and diversity indices calculation (Hammer et al., 2001).

\section{Restriction analysis (ARDRA) and reference strains}

DNA isolation, 16S rDNA gene amplification and restriction analysis of ribosomal DNA (ARDRA) using Hinfl, Mspl and Ddel endonucleases were prepared according to Teixeira et al. (2010). Twenty eight new strains were randomly selected (19 from $M$. paraibana and 9 from $M$. tenuiflora) and compared with 16 strains from Embrapa Agrobiologia bacterial diazotrophic collection: BR 7801 (Mesorhizobium loti), BR 527 (Sinorhizobium terangae), BR 7606 (Rhizobium leguminosarum bv trifoli), BR 2811 (Bradyrhizobium elkani), BR 114 (Bradyrhizobium japonicum), BR 5401 (Azospirilum doberaneae), BR5410 (Azorhizobium caulinodans), BR 2006 (Methylobacterium nodulans), BR 3407 (Burkholderia sabiae), BR 3437 (Burkholderia nodosa), BR 3454 (Burkholderia mimosarum), BR 3467 (Burkholderia mimosarum), BR 3471 (Cupriavidus taiwanensis), BR 3486 (Burkholderia phymatum), BR 3487 (Burkholderia tuberum) and BR 3498 (Burkholderia caribensis). The restriction fragment profiles were used to perform a cluster analysis using the Jaccard index, the UPMGA algorithm and the GelCompar II (Applied Maths) program. 
Table 1. General characteristics of preserved Caatinga areas in three municipalities, in the States of Paraíba (PB) and Pernambuco (PE), Brazil.

\begin{tabular}{lccc}
\hline \multirow{2}{*}{ Characteristic } & \multicolumn{3}{c}{ Municipality (state) } \\
\cline { 2 - 4 } & Santa Teresinha (PB) & Remígio (PB) & Serra Talhada (PE) \\
\hline Coordinates & $07^{\circ} 03^{\prime} \mathrm{S}$ and $37^{\circ}{ }^{\circ} 9^{\prime} \mathrm{W}$ & $6^{\circ} 52^{\prime} \mathrm{S}$ and $35^{\circ} 47^{\prime} \mathrm{W}$ & $07^{\circ} 59^{\prime} \mathrm{S}$ and $38^{\circ} 18^{\prime} \mathrm{W}$ \\
Altitude $(\mathrm{m})$ & 380 & 596 & 500 \\
Annual rainfall $(\mathrm{mm})$ & 824 & 700 & 768 \\
Months with water deficit & $9-10$ & $4-5$ & $6-7$ \\
Average temperature $\left({ }^{\circ} \mathrm{C}\right)$ & 26 & 22 & 24 \\
\hline
\end{tabular}

Table 2. Soil characteristics of preserved Caatinga areas in three municipalities, in the States of Paraíba (PB) and Pernambuco (PE), Brazil.

\begin{tabular}{lccc}
\hline \multirow{2}{*}{ Soil characteristic } & \multicolumn{3}{c}{ Municipality (state) } \\
\cline { 2 - 4 } & Santa Teresinha (PB) & Remígio (PB) & Serra Talhada (PE) \\
\hline Classification & Litholic Neosol & Regolithic Neosol & Luvisol \\
$\mathrm{pH}($ water) & 8.8 & 4.4 & 6.8 \\
$\mathrm{P}\left(\mathrm{mg} \mathrm{dm}^{-3}\right)$ & 7.3 & 8.4 & 4.9 \\
$\mathrm{~N}(\%)$ & 0.07 & 0.08 & 0.10 \\
$\mathrm{C}(\%)$ & 0.73 & 0.96 & 1.09 \\
Sand $\left(\mathrm{g} \mathrm{kg}^{-1}\right)$ & 623 & 725 & 651 \\
Silt $\left(\mathrm{g} \mathrm{kg}^{-1}\right)$ & 224 & 122 & 227 \\
Clay $\left(\mathrm{g} \mathrm{kg}^{-1}\right)$ & 153 & 153 & 122 \\
\hline
\end{tabular}

(A)

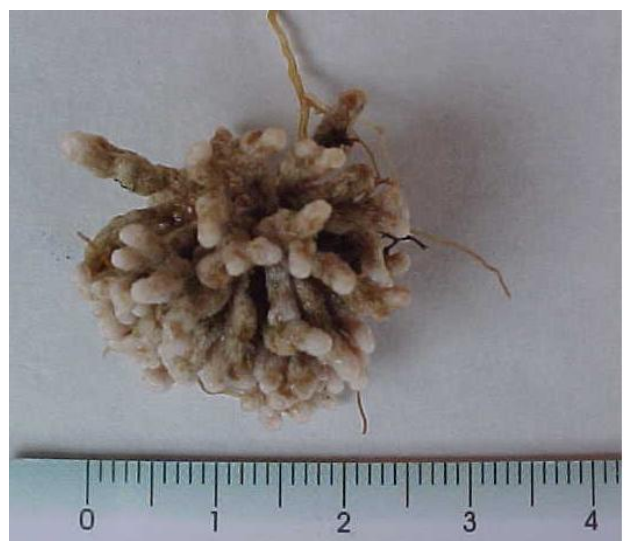

(B)

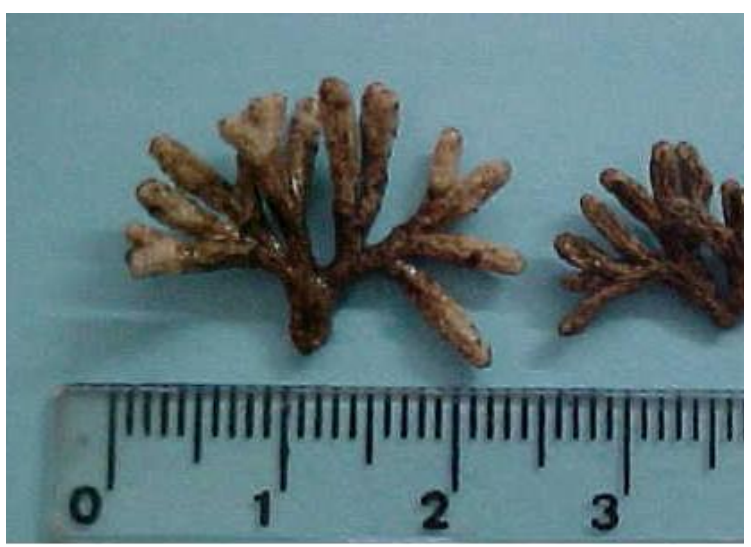

Figure 1. Shape of nodules found in Mimosa paraibana (A) and M. tenuiflora (B) roots from plants grown in soils collected under mature Caatinga vegetation.

\section{RESULTS}

\section{Mimosa spp. nodulation}

All harvested plants, cultivated in all three soils, had nodules of indeterminate growth with dark red interior and sizes up to $3 \mathrm{~cm}$ in diameter (Figure 1). Sixty one isolates were obtained from the nodules of $M$. paraibana and 62 from the nodules of $M$. tenuiflora. All isolates developed very fast, in less than $24 \mathrm{~h}$, and formed circular colonies in the YMA medium.

\section{Phenotypic characteristics of rhizobia isolates}

No isolate changed the medium $\mathrm{pH}$ to an alkaline reaction. Most of the isolates obtained from $M$. tenuiflora changed the medium $\mathrm{pH}$ to an acid reaction: $96 \%$ when 

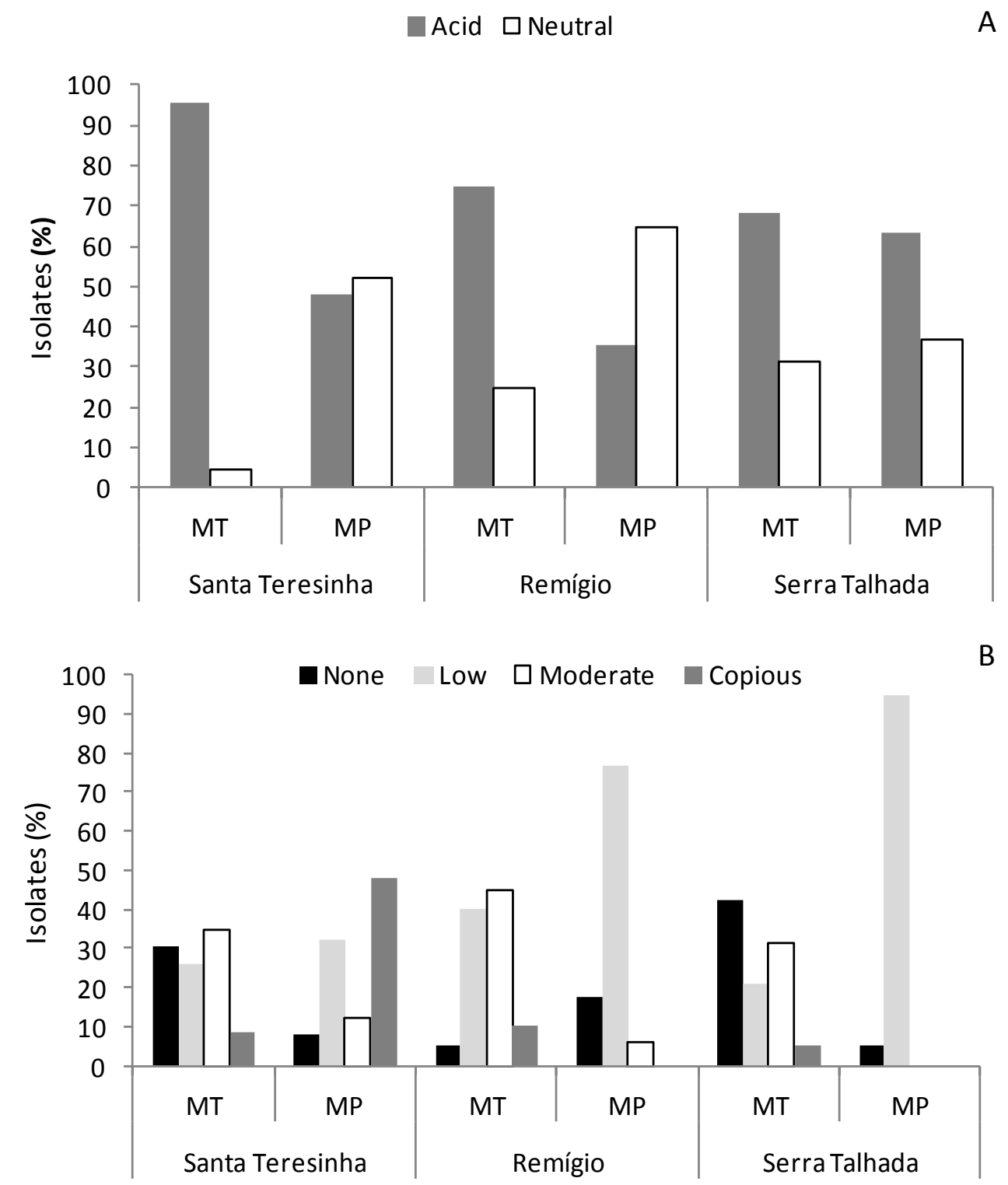

Figure 2. $\mathrm{pH}$ change $(\mathrm{A})$ and amount of extracellular polysaccharides (EPS) production (B) in YMA medium of bacterial nodule isolates from Mimosa tenuiflora (MT) and M. paraibana (MP) grown in soils collected under mature Caatinga vegetation.

when grown in the soil from Santa Terezinha, $75 \%$ in the soil from Remígio and $68 \%$ in the soil from Serra Talhada (Figure 2). Most of the isolates from M. paraibana grown in the soil from Serra Talhada (62\%) also changed the $\mathrm{pH}$ to an acid reaction but the proportions were lower in the soils from Santa Terezinha (48\%) and Remígio (35\%).

Most of the colonies had a cream color $(74 \%$ of those from $M$. tenuiflora and $67 \%$ from $M$. paraibana) but there were also white, orange and green colonies. At $48 \mathrm{~h}$ in YMA, the most common diameters of colonies from $M$. tenuiflora were punctiform (29\%), $3 \mathrm{~mm}(19 \%)$ and $4 \mathrm{~mm}$ (16\%) while those from M. paraibana were $2 \mathrm{~mm}(31 \%)$, punctiform (23\%) and $1 \mathrm{~mm}(21 \%)$. Among the isolates from $M$. tenuiflora, the highest proportion (30 to $40 \%$ in the three soils) produced colonies with moderate amounts of extracellular polysaccharides (EPS), 26\% were dry colonies and only in the colonies originating from the Santa Terezinha soil the proportion of high EPS producers $(46 \%)$ surpassed the proportion of moderate producers (Figure 2). Among the isolates from $M$. paraibana most (30 to $95 \%$ ) produced low amounts of EPS, except in the Santa Terezinha soil where the proportion of colonies with copious amounts of EPS was also high (48\%).

The isolates from $M$. tenuiflora were classified into 19 phenotypic groups and those of $M$. paraibana into 16 

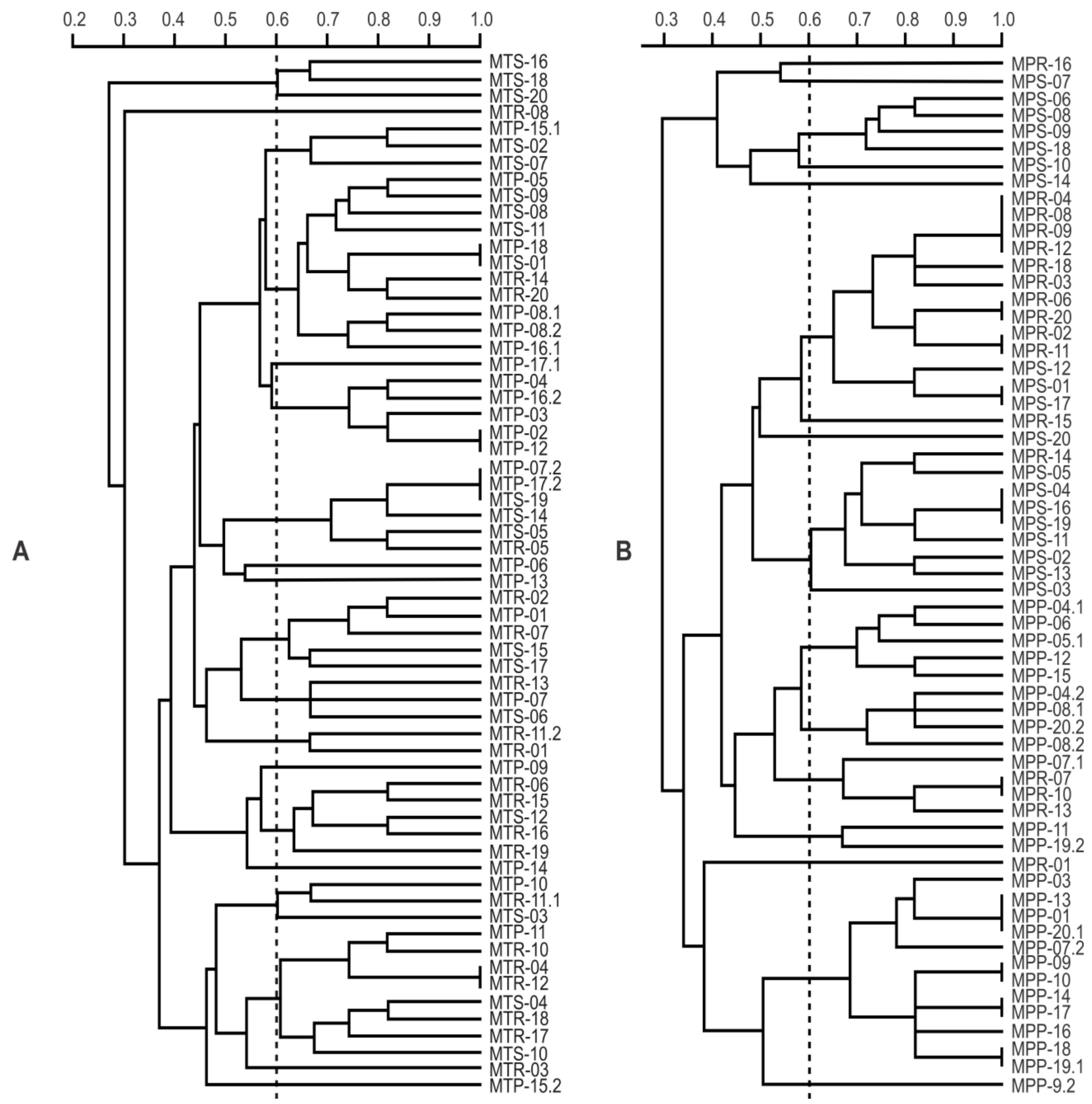

Figure 3. Phenotipic similarity dendrogram among $M$. tenuiflora $(A)$ and $M$. paraibana $(B)$ nodule isolates froms oils of preserved Caatinga. The letters MT and MP indicates the isolates from $M$. Tenuiflora and $M$. Paraibana respectively. The letters $M P, R$ and $S$ indicates isolates native from soils of Santa Terezinha, Remígio and Serra Talhada (municipalities in the States of Paraíba (PB) and Pernambuco (PE), Brazil.), respectively.

groups (Figure 3). Eight groups from each plant species were composed of a single isolate which can be considered to belong to different or rare types. The isolates from $M$. paraibana had a tendency to group according to the soil, mainly the isolates originating from the soil of
Santa Terezinha, 23 of them clustering into four groups exclusive of isolates from the soil of this area (Figure 3B). On the other hand, the isolates from $M$. tenuiflora had no clear tendency to group according to the soil.

Richness, diversity and equitability were higher among 


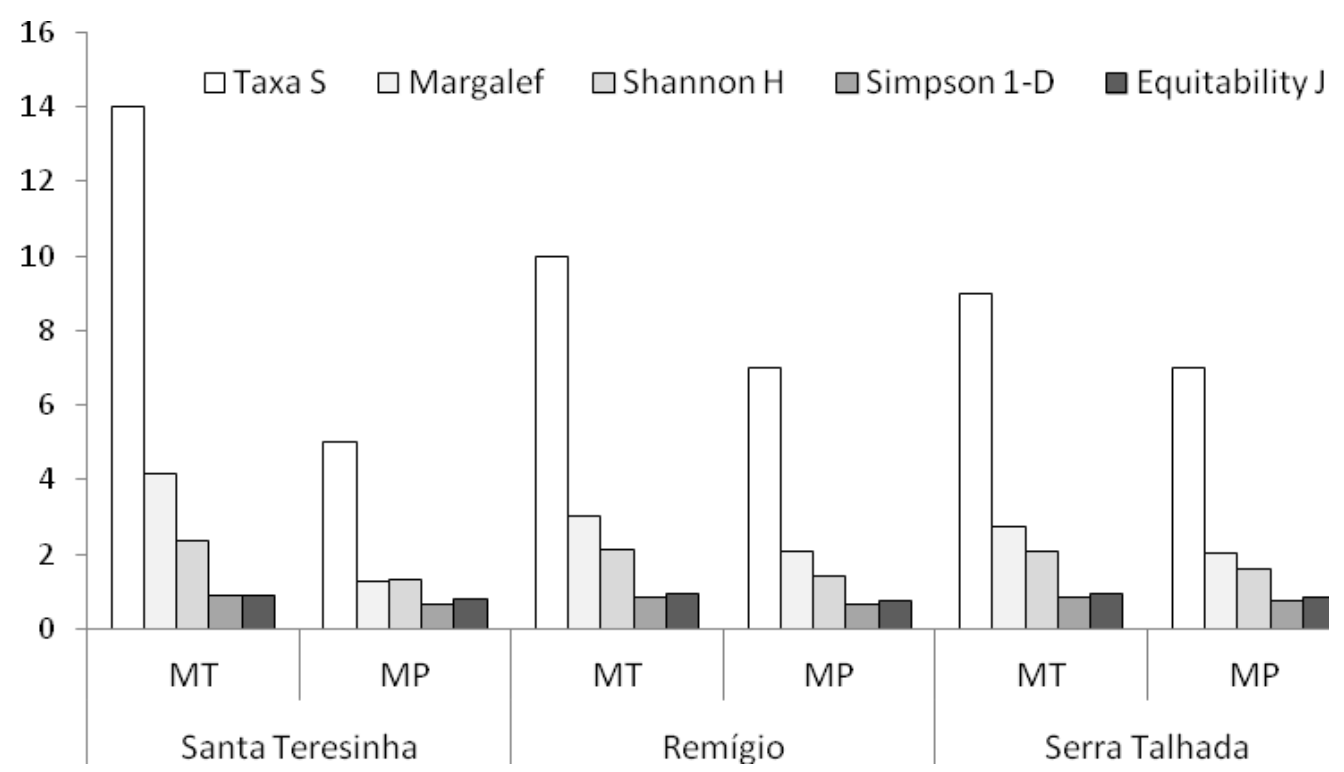

Figure 4. Taxa $\mathrm{S}$, Margalef, Shannon $\mathrm{H}$, Simpson $1-\mathrm{D}$ and Equitability $\mathrm{J}$ indices for bacterial nodule isolates from Mimosa tenuiflora (MT) and M. paraibana (MP) grown in soils collected under Mature Caatinga vegetation.

the isolates from $M$. tenuiflora than from $M$. paraibana (Figure 4). For the first species, the order of isolate diversity for the soils was Santa Terezinha, Remígio and Serra Talhada while for the second species it was the inverse order.

\section{Restriction analysis (ARDRA) cluster}

Four large groups (Figure 5) were formed in the cluster analysis based on the restriction analysis of ribosomal DNA (ARDRA). One group was composed of 26 out of 28 of the new isolates, both from M. paraibana (17 out of 19 total new isolates) and from $M$. tenuiflora (9 new isolates). The second group was somewhat related to the first group and was composed mostly of strains typical of $\beta$-rhizobia genera. The third group was composed of strains of the type typical of $\alpha$-rhizobia genera. The fourth group included only two isolates from $M$. paraibana (MPS5 and MPS10) and had a low similarity with both the $\beta$-rhizobia and the $\alpha$-rhizobia groups. Two pairs of isolates (MPS 19 and MTP 16-2; MPS 17 and MPS 12) and one groups of five isolates (MPS1, MPS6, MPS7, MPS8 and MPS9) from M. paraibana had 100\% similarity.

\section{DISCUSSION}

\section{Mimosa spp. nodulation}

The spontaneous nodulation of $M$. paraibana and $M$. tenuiflora indicates the presence, in the three soils, of native populations of bacteria able to colonize the roots of both plant species. Ample populations of nodulating bacteria are common in the soils of the regions where the legume species are native. On the other hand, nodulation frequently fails when a legume species is planted outside its original region (Bala et al., 2003; Souza et al., 2007). M. tenuiflora has a large distribution in tropical dry forests, from Brazil to Mexico (Queiroz et al., 2009) and naturally occurs in the three Caatinga fragments where the soils were collected (Ferraz et al., 2003; Pereira et al., 2003; Souza, 2010). M. paraibana has a more restricted distribution, being endemic to the Caatinga, and spontaneously occurs only in the Caatinga fragment of Remígio (Pereira et al., 2003). In spite of that, it also nodulated when planted in the soil of the two other areas. There is no information on the natural occurrence of rhizobia populations able to form symbiosis with the several Mimosa species growing in soils of the Brazilian semiarid, but the spontaneous nodulation of $M$. paraibana indicates that this occurrence may be quite general. These species may also be very promiscuous, nodulating with a large spectrum of microsymbionts, as observed for M. pudica (Bontemps et al., 2010).

The nodules of $M$. tenuiflora and $M$. paraibana were indeterminate, as has been described for those of other Mimosoideae legumes. Indeterminate nodules, with a wide range of size, formats and ramifications are usually attributed to species of Mimosoideae (Sprent et al., 2007), without influence of the microsymbionts (Lammel et al., 2007). However, some of the nodules grew more than usually reported (Patreze and Cordeiro, 2004), reaching more than $20 \mathrm{~mm}$ in their longest axis (Figure 1). M. paraibana is one of the endemic species of 


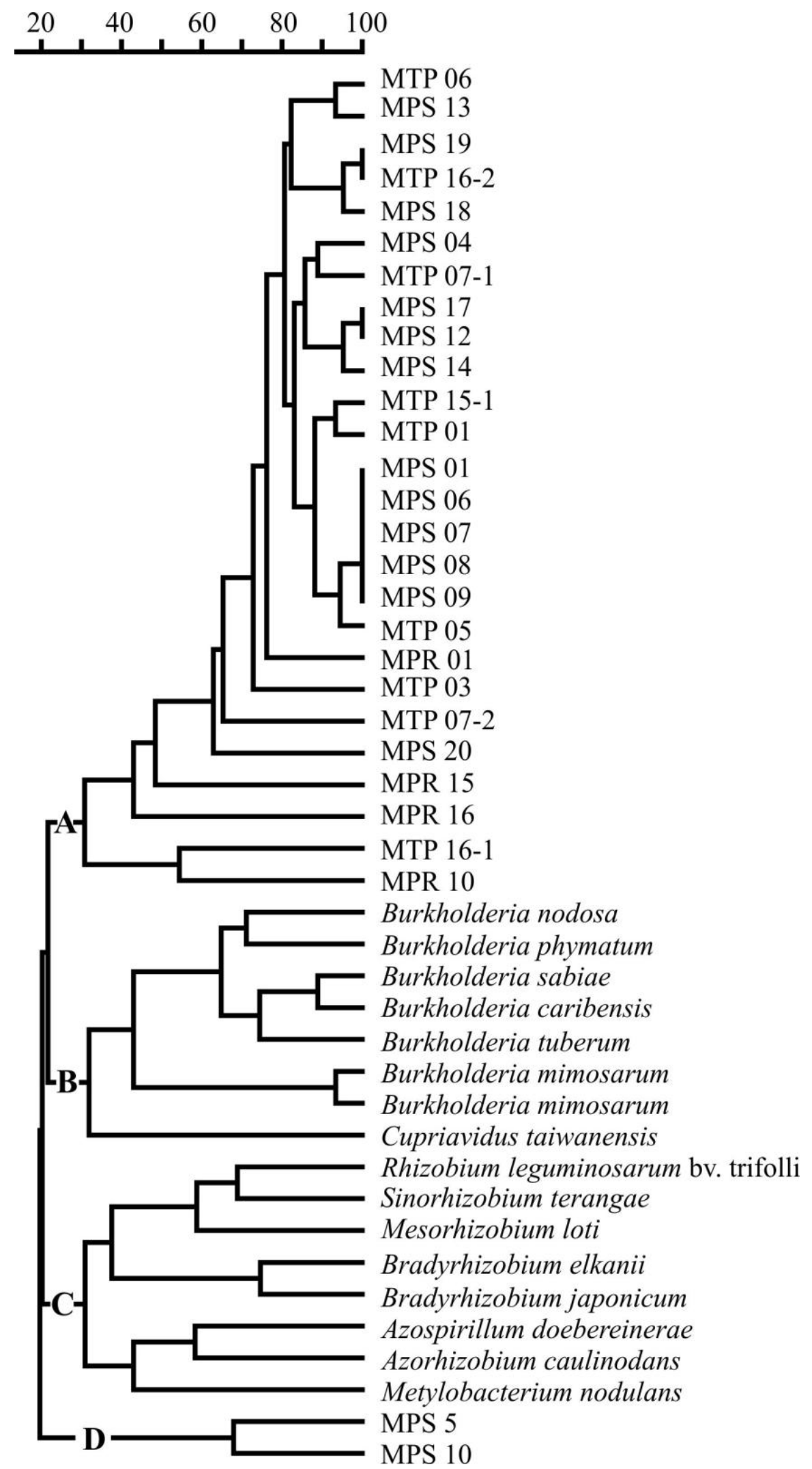

Figure 5. Genetic similarity dendrogram among 28 bacterial nodule isolates from Mimosa tenuiflora (MT) and M. paraibana (MP) grown in soils collected under mature Caatinga vegetation and $16 \alpha$ - and $\beta$-reference rhizobia strains based on PCR-ARDRA of the $16 \mathrm{~S}$ rDNA gene. 
caatinga that only recently was identified as capable of fixing nitrogen (Freitas et al., 2010) and the description of its nodules is being reported for the first time.

\section{Phenotypic characteristics of rhizobia isolates}

The growing interest on microsymbionts associated to Mimosa spp. has resulted in a large number of articles on the subject (Chen et al., 2005; Barrett and Parker, 2006; Bontemps et al., 2010; Elliott et al., 2009; Reis Jr et al., 2010; Liu et al., 2012). However, few of these articles describe the characteristics of the culture colonies formed by these symbionts. Recently, Teixeira et al. (2010) observed that all the isolates obtained from nodules of $M$. tenuiflora grown in a soil from a Caatinga area (Petrolina, Pernambuco State, Brazil) had a rapid development and acidified the medium and that most of them produced a large quantity of EPS. Fast-growing acid-producing rhizobia are the most common symbionts of several African and Asian wild tree legumes (Wolde-Meskel et al., 2004; Shetta et al., 2011). The isolates obtained from $M$. paraibana and $M$. tenuiflora cultivated in the soils from Serra Talhada, Santa Terezinha and Remígio also had rapid development but, contrasting with the African isolates, some of them did not modify the YMA culture medium $(51 \%$ of the M. paraibana isolates and $19 \%$ of the $M$. tenuiflora isolates). Large production of EPS was only observed in 17 isolates (20\% of all the M. paraibana isolates and $8 \%$ of the $M$. tenuiflora isolates). Rapid growth is a common characteristic of native isolates from the Brazilian semiarid region obtained from nodules of several species (Teixeira et al., 2010; Medeiros et al., 2009). Usually, isolates of rapid development do not form dry colonies (Teixeira et al., 2010) but this was the case in $16 \%$ of the isolates from $M$. tenuiflora and $6 \%$ of the isolates from M. paraibana (Figure 2).

White, creamy or translucent colonies are commonly formed by bacteria associated with wild tree legumes such as Acacia spp. (Wolde-Meskel et al., 2004), Millettia pinatta (Rasul et al., 2012) and Mimosa tenuiflora (Teixeira et al., 2010). White and creamy colonies also predominated among the isolates from $M$. tenuiflora and $M$. paraibana but orange and green colonies were also present. Considering that descriptions of colonies formed by rhizobia associated to Mimosa spp. are scarce (Chen et al., 2005; Bontemps et al., 2010; Reis Jr et al., 2010; Teixeira et al., 2010), it is difficult to evaluate the frequency of these phenotypes.

Medeiros et al. (2009) reported that punctiform colonies are commonly formed by isolates from nodules of Vigna unguiculata cultivated in soils from Caatinga areas. Cowpea associates with a large diversity of rhizobia and due to this characteristic it is frequently used as a trap culture (Melloni et al., 2006; Medeiros et al., 2009). However, only 29 and $23 \%$ of the isolates from the nodules of $M$. tenuiflora and $M$. paraibana formed this type of colony. Therefore, the bacteria associated with $M$. paraibana and $M$. tenuiflora seem to differ, from a certain extent, from those described in native rhizobia collections obtained from soils of the region using cowpea as a trap culture. Mishra et al. (2012) demonstrated that different legume species can form associations with different rhizobia populations, in spite of being cultivated in the same soils. The wide phylogenetic distance from cowpea and Mimosa species, belonging to two distinct legume subfamilies (Papilionoidea and Mimosoidea), may explain part of the difference in their microsymbionts.

Differences among the isolates from the two Mimosa species tested are indicated by the greater phenotypic diversity of those obtained from $M$. tenuiflora (Figure 4). This species may establish symbiosis with a larger array of rhizobia species, and this could be explained by its larger spatial distribution which may determine different patterns of co-evolution with the microsymbionts.

\section{Analysis of the 16S rDNA gene}

The analysis of the 16S rDNA gene suggests that the isolates from $M$. tenuiflora and $M$. paraibana are closely related, independently from the soil of cultivation, clustering in the first group of the dendrogram (Figure 5). All isolates show the same phenotypic characteristics of mucus production, acid or neutral reaction and homogeneous and circular colonies. Other characteristics such as differences in color of colonies and amount of mucus generated clustering on phenotypic dendrograms that cannot be observed in the genetic analysis. They were also closer related to $\beta$-rhizobia than to $\alpha$-rhizobia, corroborating previous reports of prevalence of this group among species of the Mimosoideae subfamily (Chen et al., 2005; Reis Jr et al., 2010). However, the similarity with all the tested $\beta$-rhizobia reference strains was relatively low.

Two isolates (MPS5 and MPS10) are clustered apart these two groups. According to their position they could be alpha that were not well resolved by the analysis, or another class of proteobacteria.

\section{Conclusion}

The results demonstrate that the bacteria populations from the nodules of Mimosa spp. species native from the soils of the semiarid Brazilian region have cultural characteristics different from those obtained from the same soils but using other legume species as trap plants. In spite of fast growth, the isolates can form from dry colonies to colonies with large production of EPS. The isolates are more related to $\beta$-rhizobia than to $\alpha$-rhizobia, but the low similarity with the strains from the Embrapa collection suggests that the rhizobia isolated from the nodules of $M$. tenuiflora and $M$. paraibana are different bacteria species. 


\section{REFERENCES}

Albuquerque UP, Araújo EL, El-Deir ACA, et al. (2012) Caatinga revisited: ecology and conservation of an important seasonal dry forest, The Scientific World Journal: $18 \mathrm{p}$.

Bala A, Murphy PJ, Osunde AO, Giller KE (2003). Nodulation of tree legumes and the ecology of their native rhizobial populations in tropical soils. Appl. Soil Ecol. 22:211-223.

Barrett CF, Parker MA (2006). Coexistence of Burkholderia, Cupriavidus, and Rhizobium sp. nodule bacteria on two Mimosa spp. in Costa Rica. Appl. Environ. Microbiol. 77:1198-1206.

Bontemps C, Elliott GN, Simon MF, Reis Jr FB, Gross E, Lawton RC, Elias Neto N, Loureiro MF, Faria SM, Sprent JI, James EK, Young JPW (2010). Burkholderia species are ancient symbionts of legumes. Mol. Ecol. 19:44-52.

Chen WM, Faria SM, Straliotto R, Pitard RM, Araújo JLS, Chou JH, Chou YJ, Barrios E, Prescott AR, Elliott GN, Sprent JI, Young JPW, James EK (2005). Proof that Burkholderia strains form effective symbioses with legumes: a study of novel Mimosa-nodulating strains from South America. Appl. Environ. Microbiol. 71:7461-7471.

Elliott GN, Chou JH, Chen WM, Bloemberg GV, Bontemps C, MartínezRomero E, Velázquez E, Young JPW, Sprent JI, James EK (2009).Burkholderia spp. are the most competitive symbionts of Mimosa, particularly under $\mathrm{N}$-limited conditions. Environ. Microbiol. 11(4):762-778.

EMBRAPA - Embrapa Brasileira de Pesquisa Agropecuária (1997). Manual de métodos de análise de solos, Embrapa, Rio de Janeiro.

Ferraz EMN, Rodal MJ, Sampaio EVSB (2003).Physiognomy and structure of vegetation along an altitudinal gradient in the semi-arid region of northeastern Brazil. Phytocoenologia 33:71-92.

Fred EB, Waksman SA (1958) Laboratory manual of general microbiology. Mc Grow Hill, New York.

Freitas ADS, Sampaio EVSB, Fernandes AR, Santos CERS (2010). Biological nitrogen fixation in legume trees of the Brazilian Caatinga. J. Arid Environ. 74:344-349.

Hammer $\varnothing$, Harper DAT, Ryan PD (2001). Past: paleontological statistics software package for education and data analysis. Palaeontologia Electronica 4:1-9

Hoagland DR, Arnon DI (1939). The water culture method growing plants without soil. U Calif Agric Exp Sta, California.

Jesus EC, Moreira FMS, Florentino LA, Rodrigues MID, Oliveira MS (2005). Diversidade de bactérias que nodulam siratro em três sistemas de uso da terra da Amazônia Ocidental. Pesq. Agropecu. Bras. 40:769-776.

Lammel DR, Brancalion PHS, Dias CTS, Cardoso EJBN (2007). Rhizobia and other legume nodule bacteria richness in brazilian Araucaria angustifolia forest. Sci. Agric. 64(4):400-408.

Liu XY, Wei1 S, Wang F, James EK, Guo XY, Zagar C, Xia LG, Dong X, Wang YP (2012).Burkholderia and Cupriavidus spp. are the preferred symbionts of Mimosa spp. in Southern China. FEMS Microbiol. Ecol. 80:417-426

Medeiros EV, Martins CM, Lima JAM, Fernandes YTD, Oliveira VR, Borges WL (2009). Diversidade morfológica de rizóbios isolados de caupi cultivado em solos do Estado do Rio Grande do Norte. Acta. Sci. Agron. 31(3):529-535.

Melloni R, Moreira FMS, Nóbrega RSA, Siqueira JO (2006). Eficiência e diversidade fenotípica de bactérias diazotróficas que nodulam caupi (Vigna unguiculata (L.) Walp) e feijoeiro (Phaseolus vulgaris L.) em solos de mineração de bauxita em reabilitação R. Bras. Ci. Solo. 30:235-246.

Mishra RPN, Tisseyre $\mathrm{P}$, Melkonian R, Chaintreuil $\mathrm{C}$, Miché L, Klonowska A, Gonzalez S, Bena G, Laguerre G, Moulin L. (2012). Genetic diversity of Mimosa pudica rhizobial symbionts in soils of French Guiana: investigating the origin and diversity of Burkholderia phymatum and other beta-rhizobia. FEMS Microbiol. Ecol. 79:487503.
Patreze CM, Cordeiro L (2004). Nitrogen-fixing and vesicular arbuscular mycorrhizal symbioses in some tropical legume trees of tribe Mimoseae. Forest Ecology and Management. 196: 275-285.

Pereira IM, Andrade LA, Sampaio EVSB, Barbosa MRV (2003). Usehistory effects on structure and flora of Caatinga. Biotropica. 35:154165.

Queiroz LP (2006). The Brazilian Caatinga: phytogeografical patterns inferred from distribution data of the Leguminosae. In: Pennington $T$, Lewis GP, Ratter JA (eds) Neotropical Savannas and Seasonally Dry Forests Plant Diversity, Biogeography and Conservation, CRC Press,New York, pp 121-157.

Queiroz LP (2009). Leguminosas da Caatinga, Universidade Estadual de Feira de Santana, Royal Botanic Gardens Kew, Associação Plantas do Nordeste, Feira de Santana.

Rasul A, Amalraj ELD, Kumar GP, Grover M, Venkateswarlu B (2012). Characterization of rhizobial isolates nodulating Millettia pinnata in India. FEMS Microbiol. Lett. 336:148-158.

Reis Jr FB, Simon MF, Gross E, Boddey RM, Elliott GN, Neto NE, Loureiro MF, Queiroz LP, Scotti MR, Chen WM, Norén A, Rubio MC, Faria SM, Bontemps C, Goi SR, Young JPW, Sprent JI, James EK (2010). Nodulation and nitrogen fixation by Mimosa spp. in the Cerrado and Caatinga biomes of Brazil. New Phytol. 186:934-946.

Shetta ND, Al-Shaharani TS, Abdel-Aal M (2011). Identification and characterization of Rhizobium associated with woody legume trees grown under Saudi Arabia condition. Am. Eurasian J. Agric. Environ. Sci. 10:410-418.

Simon MF, Grether R, Queiroz LP, Särkinen TE, Dutra VF, Hughes CE (2011). The evolutionary history of Mimosa (Leguminosae): toward a phylogeny of the sensitive plants. Am. J. Bot. 98(7):1201-1221.

Souza LAG, Bezerra Neto E, Santos CERS, Stamford NP (2007). Desenvolvimento e nodulação natural de leguminosas arbóreas em solos de Pernambuco. Pesq Agropec Bras. 42(2):207-217.

Souza LQ (2010). Fitossociologia em áreas com diferentes históricos de uso e fixação biológica de nitrogênio em Caatinga madura na Paraíba. M.Sc. dissertation, Universidade Federal de Pernambuco, Brazil.

Souza LQ, Freitas, ADS, Sampaio EVSB, Moura PM, Menezes RSC (2012). How much nitrogen is fixed by biological symbiosis in tropical dry forests? 1. Trees and shrubs. Nutr. Cycl. Agroecosist. 94:171179.

Sprent JI (2007). Evolving ideas of legume evolution and diversity: a taxonomic perspective on the occurrence of nodulation. New Phytol. 174:11-25.

Teixeira FCP, Borges WL, Xavier GR, Rumjanek NG (2010). Characterization of indigenous rhizobia from caatinga. Braz $\mathrm{J}$ Microbiol. 41:201-208.

Vincent JM (1970). A manual for the practical study of root nodule bacteria, Blackkwell Scientific, Oxford.

Wolde-Meskel E, Berg T, Peters NK, Frostegard A (2004) Nodulation status of native woody legumes and phenotypic characteristics of associated rhizobia in soils of southern Ethiopia. Biol. Fertil. Soils. 40:55-66.

Xavier GR, Martins LMV, Neves MCP, Rumjanek NG (1998). Edaphic factors as determinants for the distribution of intrinsic antibiotic resistance in a cowpea rhizobia population. Biol. Fertil. Soils. 27:386392. 